\title{
Effects of Climatic Factors on The Incidence Rate of Dengue Virus Infection in Surabaya During 2010- 2013
}

\author{
Winni Aprillia Putri ${ }^{1}$, Abu Rohiman $^{2}$, Sulistiawati $^{3}$, Dwiyanti Puspitasari ${ }^{4 *}$ \\ ${ }^{1}$ Faculty of Medicine Universitas Airlangga, Surabaya, Indonesia \\ ${ }^{2}$ Department of Microbiology, Faculty of Medicine Universitas Airlangga, Surabaya, Indonesia - Dr. Soetomo General \\ Hospital Surabaya, Indonesia \\ ${ }^{3}$ Department of Public Health and Preventive Medicine, Faculty of Medicine Universitas Airlangga, Surabaya, Indonesia - \\ Dr. Soetomo General Hospital Surabaya, Indonesia \\ ${ }^{4}$ Department of Pediatric, Faculty of Medicine Universitas Airlangga, Surabaya, Indonesia - Dr. Soetomo General Hospital \\ Surabaya, Indonesia
}

\section{A R T I C L E I N F O}

\section{Article history:}

Received 11 April 2019

Received in revised form 24 May 2019

Accepted 26 June 2019

Available online 30 June 2019

\section{Keywords:}

Dengue Virus Infection,

Precipitation,

Temperature,

Humidity,

Incidence.

*) Corresponding author: yanti@dr.com

\begin{abstract}
A B S T RA C T
Introduction: Dengue Virus Infection (DVI) is one of cautious mosquito-borne virus disease that transmitted by Aedes aegypti and Aedes albopictus. Surabaya has the highest incidence rate of DVI in East Java. Transmission of dengue virus were significantly affected by the change of climatic factor components (precipitation, temperature, and humidity). This study is aimed to analyze the correlation between climatic factor components with the incidence rate of DVI in Surabaya and its distribution.

Methods: This is a cross-sectional study using analytic observational approach. The Incidence rate of DVI during 2010-2013 datas were taken from Surabaya Health Office. Climatic factor datas on the same years were taken from Juanda Meteorological Station. Correlation tests were performed by using Spearman Test.

Results: As the result, there were 7,685 DVI patients during 2010-2013. Male patients have less proportion (51.89\%). The highest DVI cases are from the age group of 5-14 years ( $>40 \%)$. Incidence rate of DVI was increased during February to April, and highest incidence rate occured in 2010 $(n=3,379)$. There were significant correlation between precipitation $(r=0.419$, $p$-value $p=0.003)$ and humidity $(\mathrm{r}=0.502$, $\mathrm{p}$-value $=0.000)$ with the incidence rate of DVI in Surabaya during 2010-2013. Conclusion: Therefore, precipitation and humidity are two climatic factor components that may effect the incidence rate of DVI in Surabaya.
\end{abstract}

\section{Introduction}

Dengue Virus Infection (DVI) is an infectious disease caused by one of arthropods borne virus with RNA genome, dengue virus. This flaviviridae family has 4 serotypes, those are DEN-1, DEN-2, DEN-3, and DEN-4. Dengue virus is carried and transmitted by Aedes aegypti and Aedes albopictus. ${ }^{1}$ DVI early discovered in sixties decade, and began to expand to the Southeast Asia country region, such as: Singapore, Malaysia, Sri Lanka, and Indonesia. In Indonesia, this disease firstly found in Surabaya on 1968, and shortly spread through all regions in Indonesia. ${ }^{2}$

Recent study shows that there has been an increased number, 30 folds of DVI cases in the last five decades. Southeast Asia region has labeled as DVI hyperendemic area since 2000 . About 2.5 billion people at risk of infection every year. 1 In Indonesia, DVI had spread in 33 provinces and 440 cities since 2010. Java island has Incidence Rate (IR) up to 65.62/100,000 and dan Case Fatality Rate (CFR) up to $0.87 \% .3$ Surabaya is placed on the first rank of big five cities with highest incidence rate of DVI in East Java. ${ }^{4}$

Factors that affect amount of DVI cases are very complex, like population growth rate escalation, uncontrolled urbanization, and also vector control failure in endemic areas. ${ }^{2}$ Transmission pattern of dengue virus by mosquito is highly correlated with climatic factor components, this could be happened since dengue virus and its vector are very sensitive with climatic change, especially precipitation, temperature, and humidity. ${ }^{5}$ Global warming as one of world

Biomolecular and Health Science Journal

Available at https://e-journal.unair.ac.id/BHSJ ; DOI: 10.20473/bhsj.v2i1.9340 
biggest problem, also triggers an unpredictable climatic change. The increasing of air temperature from global warming caused vector distribute and invade to the host rapidly. Each component of climatic factor has different mechanism in affecting vector density. ${ }^{6}$ Furthermore, vector density has an important role in DVI cases endemicity in an area. ${ }^{7}$ Those factors also affect the number of morbidity and mortality of DVI patients, beside host immunity itself and geographical condition. ${ }^{2}$

Topographically, Surabaya included into lowland areas (height of $<45$ meters). ${ }^{4}$ As well as other tropical regions, Surabaya has two seasons. The rainy season lasts during November to April. Average precipitation is $172 \mathrm{~mm}$ and increased in the the rainy season up to $200 \mathrm{~mm} / \mathrm{months}$. Maximum temperature can reach $30^{\circ} \mathrm{C}$, while the minimum temperature is $25^{\circ} \mathrm{C}$. Air humidity ranging from $47 \%$ $88 \% .^{3}$ Due to each precipitation, temperature, and humidity pattern in each area and season, the fluctuation of incidence rate will also make different. In East Java, DVI cases are commonly found in early January and continuously increase a few months ahead. ${ }^{2}$ Study about this field is still lacking. Therefore, this study is aimed to analyze the effect of climatic factors (precipitation, temperature, and humidity) on the incidence rate of DVI in Surabaya.

\section{Methods}

This was a cross-sectional study. This study was conducted in Surabaya Principal Health Office and Juanda Meteorological Station Surabaya, started from November 2014 until March 2015. We collected climatic factor components (precipitation, temperature, and humidity) and the distribution of DVI incidence rate by sex and age group from the date of January 1st, 2010 to December 31st, 2013.

All datas obtained, processed and computed using SPSS for windows version 12 (IBM Corp.). Univariate analysis test was helped in illustrating the distribution of DVI incidence rate by sex, age group, and the fluctuation of each climatic factor components. Meanwhile, bivariate analysis was done using Kolmogorov-Smirnov test and Spearman Correlation Test with $\mathrm{p}<0.05$ considerated as significant.

\section{Results}

\section{Overview of Dengue Virus Infection (DVI) Incidence}

The table 1 shown below, presented the number of incidence rate of DVI during 4 years periods (2010-2013).

Table 1. Incidence Rate of Dengue Virus Infection in Surabaya during 2010-2013

\begin{tabular}{cccc}
\hline Year & Total Cases & Population & $\begin{array}{c}\text { Incidence } \\
\text { Rate (IR) }\end{array}$ \\
\hline 2010 & 3,379 & $2,929,528$ & 115.34 \\
2011 & 1,008 & $3,024,321$ & 33.33 \\
2012 & 1,091 & $3,125,576$ & 34.91 \\
2013 & 2,207 & $3,200,454$ & 68.96 \\
\hline
\end{tabular}

The number ofDVI patients in 2010 is the highest, compared to the other years. It was also recorded that the incidence rate of DVI tends to be high in the beginning of the year.It was found that the total number of DVI male patients during 4 years as many as 3,987 patients $(51.89 \%)$. Meanwhile, the female were about 3,697 patients (48.11\%). Although, there is little difference in 2012, it can be concluded that in 4 years (20102013), the average of DVI patients between male and female is almost the same each year. DVI patients in Surabaya are divided into 5 age groups. From this study, $>40 \%$ DVI patients during 4 years are people in the age group of 5-14 years and $<1$ year age group $(<5 \%)$ has the smallest percentage.

The fluctuation of DVI patients in 4 years (2010-2013) is almost the same each year. Monthly distribution of DVI patients during the study periods can be seen in figure 1 below.

Incidence rate of DVI escalated from January to March, and also has a sharp decline from June-September. In 2010, there was an anomaly of incidence rate number, where in May and June the rate was still high, compared to other years. It can be concluded that the distribution patterns of DVI patients during 4 years were relatively the same.

\section{Climatic Factor Components Variation Overview in Surabaya}

Various climatic factor components data in Surabaya during 2010 to 2013, consisted of 3 variables, those are precipitation, temperature, and humidity. Monthly precipitation in Surabaya is relatively high in December and decreased slowly with intensity remained high until April. Highest precipitation is in 2010 (262.6 mm/month). Meanwhile, the lowest precipitation (116.4 mm/month) occurred in 2012. According to the Oldeman seasonal criteria, 2010 and 2013 were categorized as wet months (average precipitation of $>200 \mathrm{~mm} / \mathrm{month}$ ). Meanwhile, 2011 and 2012 were categorized as moist months (average precipitation of 100-200 mm/month).

The highest mean temperature was in 2010 , about $27,97^{\circ} \mathrm{C}$. Fluctuation in temperature each month as average of daily temperatures within 4 years not showing any significant ups and downs (relative low fluctuation). According to the Class I Meteorological Station Juanda Surabaya, the average of minimum temperature in Surabaya during 4 years about $21.8^{\circ} \mathrm{C}-25.8^{\circ} \mathrm{C}$ and the average of maximum temperature about $30^{\circ} \mathrm{C}-34.2^{\circ} \mathrm{C}$. Of the two kinds of independent variables that have been described previously, humidity have more fluctuated each month. Highest average air humidity was occurred in $2010(79.42 \%)$. While the lowest humidity was occurred in 2012 with an average of $76.12 \%$.

\section{The Effect of Precipitation on The Incidence Rate of DVI}

Through the correlation test done, resulted that monthly precipitation affects the incidence rate of DVI patients $(r=0.419, p=0.003)$. From the diagram below showed that in certain months with high precipitation will be followed by a rise in the incidence of DVI. See figure 2.

\section{The Effect of Air Temperature on The Incidence Rate of DVI}

From data analysis showed that air temperature is not significantly correlated on the incidence rate of DVI $(r=0.020$, $\mathrm{p}$-value $=0.894)$ (Figure 3).

The Effect of Air Humidity on The Incidence Rate of DVI The last climatic factor tested here is the air humidity and as the result, humidity is positively correlated to the incidence rate of DVI (r=0.502, p-value=0.000). See figure 4 . 
Figure 1. Monthly Distribution of Dengue Virus Infection Patients

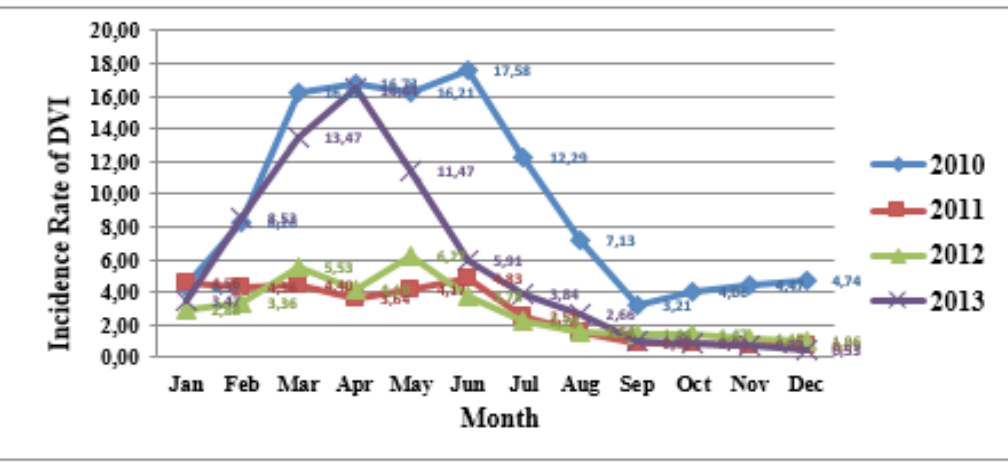

Figure 2. The Effect of Precipitation on the incidence rate of DVI Diagram

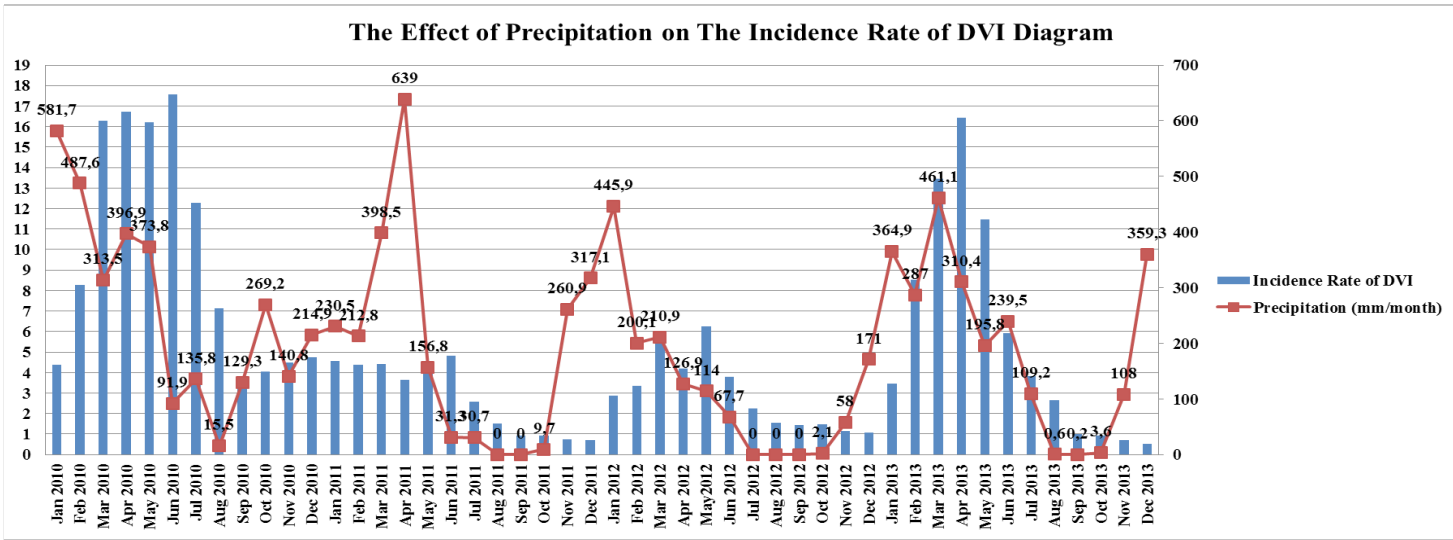

Figure 3. The Effect of Air Temperature on the incidence rate of DVI Diagram

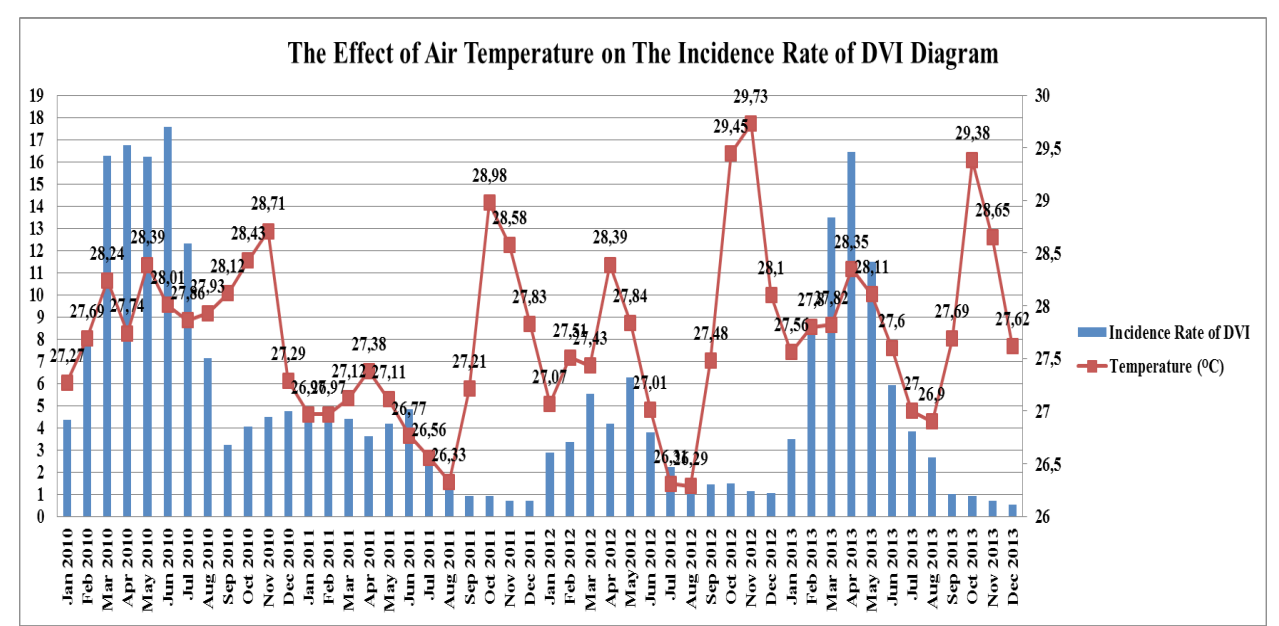

Figure 4. . The Effect of Air Humidity on the incidence rate of DVI Diagram

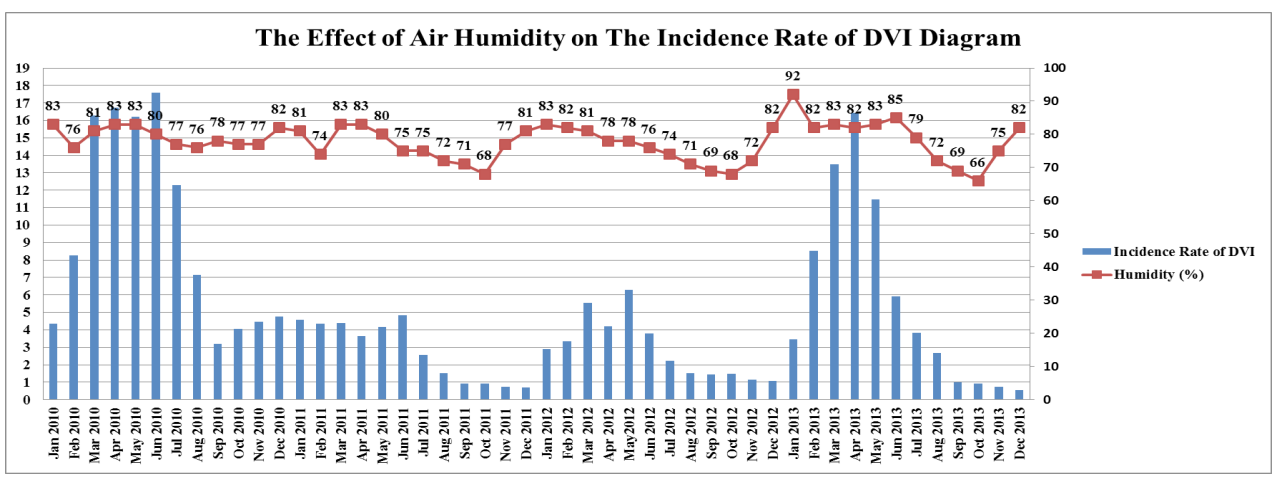




\section{Discussion}

Study about the effect of climatic factors on the DVI incidence rate give different result in each area. Surabaya with its topographic tend to has less temperature fluctuation but high and moderate precipitation and air humidity fluctuation. A result that must be highlighted from this study that air humidity is the strongest climatic factor that affect DVI incidence rate, followed by air humidity.

Alshehri (2013) stated that every year, about 2.5 million people worldwide are populations at high risk of DVI.8 Many factors affect the incidence of DVI, one of the most highlighted and continues to be the target of intervention by a lot of researchers is the spread and density of mosquitoes. Several studies have shown that age is a variable that is considered strongly affect the incidence of DVI. In this study, age group with the highest DVI cases is 5-14 years age group, while the age group with the smallest incidence is $<1$ year age group. This result is in contrast to a study conducted by Thai et al (2011), which shows that the highest incidence is in the adult age group (15-44 year). 9 Male patients percentage was slightly higher than the female. It is in line to a research conducted by Anker in 2011 that said in 6 Asian countries, the number of male patients was relatively higher in the $15-44$ year age group. ${ }^{10}$

Therefore some influencing aspects of DVI. The first is related to the spatial aspect. Spatial aspect can be interpreted as an aspect that has a geographic reference. A region to the others have different characteristics on ground surface height, soil type, population density and behaviour, hygiene level, and many more. ${ }^{11}$ Geographical condition of Indonesia in general, and Surabaya in particular, with its tropical climate potentially become a hyperendemic DVI area. The development of complex urban area slowly degrade the quality of the environment and affect the expansion of the Aedes aegypti habitat. The tendency of people that highly active in economic bussiness impacts in to the gas emission and increases the earth average temperature by $1^{\circ} \mathrm{C}-3.5^{\circ} \mathrm{C}$. Surabaya is an ideal place for the breeding sites of Aedes aegypti by having an average air temperature of $27.85^{\circ} \mathrm{C}$ with an average humidity of $75.75 \% .^{12}$

The second, DVI also need to be evaluated based on the temporal aspect. Through this aspect, researcher get a disease fluctuation pattern by the time. ${ }^{11}$ From this study, authors found that DVI cases in Surabaya is relatively high in February until April, then began to decline in May. Precipitation, air temperature, air humidity along with several other climatic factor components are several main contributors for the high number of DVI cases. Precipitation improves the transmission of vector-borne disease by supply more breeding places. ${ }^{13}$ Outdoor breeding places such as, dry waste bottles, cans, pieces of bamboo as fence, which is often found in the houses, is possible to collect much rain water and then become a better place to lay eggs. ${ }^{14}$ Precipitation and air temperature influence the incidence rate of DVI interdependently. A rise in air temperature will accelerate evaporation and reduce the quantity of water in the breeding sites. Increased air humidity is strongly associated with vector adaptation in resting and breeding. A study has showed that increase in precipitation a few months earlier will be significantly improve larval density. In the water habitat, competition for space and nutrients are also affected by the water conditions in that place. ${ }^{15}$ However, precipitation itself is also a factor that can eliminate the breeding places by immerse all of them. ${ }^{13}$ This might be an explanation about the correlation between precipitation and the incidence rate. Another explanation is when incidence rate is peak in February to April, increased precipitation has actually happened 3 to 4 months earlier. The results of this study are similar to previous research in Banjarbaru, South Kalimantan during 2005-2010. ${ }^{16}$

WHO stated that the air temperature is correlated with the sustainability of vector. Correlation between solar radiation with DVI cases are indirectly because the light only affect the mosquitoes habit in foodseeking and find a place to rest. Aedes aegypti have a habit to rest in a dark place and shielded from sunlight, so are in the habit of laying eggs. ${ }^{12}$ Through correlation analysis, resulted that the air temperature variation within 4 years are about $29.29^{\circ} \mathrm{C}$ $29.73^{\circ} \mathrm{C}$, while variation in humidity are about $62 \%-92 \%$ with a mean annual air humidity of $77.83 \%$. The result of this study is in line to the research conducted by Costa et al. (2010) that said, a condition with $35^{\circ} \mathrm{C}$ in temperature and $60 \%$ in humidity will decrease the oviposition rate of mosquito (an average of $54.53 \pm 4.81$ eggs), while the air temperature of $25^{\circ} \mathrm{C}$ and $80 \%$ in air humidity are potential for vectors oviposition rate (an average of $99.08 \pm 3.56$ eggs). ${ }^{17,18}$ Air temperature in Surabaya, which tend to be higher, not illustrate a significant correlation on the incidence rate of DVI $(\mathrm{r}=0.020)$, whereas high humidity is met to the criteria for breeding sites and is a variable that correlates fairly strong $(\mathrm{r}=0.502)$. This result is similar to other studies carried out in different places. ${ }^{16,19,20}$ In contrast, Maslukha (2010) in her study at Sidoarjo during 2005-2009, proved that air temperature significantly affects the incidence rate of DVI.21 For air humidity variable, this study results are not much different from the research done previously. ${ }^{16,19}$ But, it is in contrast with the result of study by Fitriany et al. (2010). It might happened due to the short study period, so that the test result is less significant. According to Bhatia (2013), humidity gave the greatest correlation on the incidence rate of DVI, therefore air humidity has been discovered as the critical causal factor of DVI. The ability of mosquitoes to survive has decreased in dry conditions. ${ }^{12}$ Gobler in Roose (2008) mentioned that, humidity also affects the life span of vector. ${ }^{22}$ It is said that humidity is not directly correlated with DVI cases, but with the age of mosquitoes. At low humidity, the mosquitoes have not enough time to transfer the virus from the stomach to the salivary glands. Therefore, the mosquito requires a humidity of more than $60 \%$ to life longer and potentially breeds. $^{18}$

In Indonesia, the difference of precipitation pattern is an important factor to determine how much climatic factors can affect the incidence rate of DVI. There are several factors that influence the incidence rate of DVI as much as climatic factors. Among these factors are urbanization and the making of artificial habitat for breeding sites. One more variable that mostly contribute is herd immunity that can change the demographic transmission of dengue virus. $^{23}$ Furthermore, according to Reiter et al. (2003), socio-economic factor that vary in each region is a special contributor that should receive more attention. Indonesia as a developing country with most suburban communities 
in it, has high potential to trigger the increased of vectorborne transmission of the virus itself. ${ }^{24}$

In this study there is a factor that not examined because the study scope of DVI incidence rate assessment, is the number of free larvae. The number of free larvae assessed using an activity called vector surveillance. This action consists of routine practice in many endemic countries due to avoid the outbreak of DVI any time and also increase the wary. The standard protocol is specified with stegomyia invention, a form of immature vector (larval phase). However, this protocol weakly correlated with the density of adult mosquito population. A method that is more accurate, but still rarely applied is the discovery of an adult female Aedes aegypti. ${ }^{22}$

\section{Conclusion}

The highest incidence rate of DVI in Surabaya during 4 years was in 2010. Generally, all climatic factor components have high variation each year, but the biggest average of precipitation, temperature, and humidity was in 2010. Highest amount of precipitation was found in December to April. Precipitation and air humidity are two climatic factors that give greater change to the incidence rate of DVI.

\section{Conflict of Interest}

The author stated there is no conflict of interest

\section{References}

1. Bhatia R, Dash AP and Sunyoto T. Changing epidemiology of dengue in South-East Asia. WHO South-East Asia Journal of Public Health. 2013; 2 : 23-7.

2. DepKes. Pencegahan dan Pemberantasan Demam Berdarah Dengue di Indonesia. Jakarta2007.

3. DitjenP2PL. Situasi Penyakit Tahun 2011 Dibandingkan Tahun 2010. 2012.

4. DKPJATIM. Profil Kesehatan Provinsi Jawa Timur. Surabaya, 2012.

5. Hopp MJ and Foley JA. Global Scale Relationships between Climate and the Dengue Fever Vector, Aedes Aegypti. Climatic Change. 2001; 48: 441-63.

6. Guzman A and Isturiz RE. Update on the Global Spread of Dengue. International Journal of Antimicrobial Agents. 2010; 36 Suppl 1: S40-2.

7. Simmons CP, Farrar JJ, Nguyen v V and Wills B. Dengue. The New England Journal of Medicine. 2012; 366: 1423-32.
8. Alshehri and Saeed. Dengue Fever Outburst and its Relationship with Climatic Factors. World Applied Sciences Journal. 2013; 22: 506-15.

9. Thai KT, Nishiura H, Hoang PL, et al. Age Specificity of Clinical Dengue During Primary and Secondary Infections. PLoS Neglected Tropical Diseases. 2011; 5: e1180.

10. Anker M and Arima Y. Male Female Differences in the Number of Reported Incident dengue Fever Cases in Six Asian Countries. Western Pacific Surveillance and Response journal : WPSAR. 2011; 2: $17-23$.

11. Mangguang M. Analisis Epidemologi Penyakit Demam Berdarah Dengue melalui Pendekatan Spasial Temporal dan Hubungannya degan Faktor Iklim di Kota Padang Tahun 2008-2010. Forum Informatika Kesehatan Indonesia. 2011.

12. Fidayanto R, Susanto H, Yohanan A and Yudhastuti R. Model Pengendalian Demam Berdarah Dengue. 2013. 2013: 7.

13. Iriani Y. Hubungan antara Curah Hujan dan Peningkatan Kasus Demam Berdarah Dengue Anak di Kota Palembang. Sari Pediatri. 2012; 13.

14. Faldy R. Pemetaan Kasus Demam Berdarah Dengue di Kabupaten Minahasa Utara. Jurnal Kedokteran Komunitas dan Tropik. 2015; 3.

15. Morin CW, Comrie AC and Ernst K. Climate and dengue transmission: evidence and implications. Environmental health perspectives. 2013; 121: 1264-72.

16. Zubaidah T. Climate change impact on dengue haemorrhagic fever in Banjarbaru South Kalimantan between 2005-2010. Jurnal Epidemiologi dan Penyakit Bersumber Binatang. 2012; 4.

17. Costa EAPdA, Santos EMdM, Correia JC and Albuquerque CMRd. Impact of Small Variations in Temperature and Humidity on the Reproductive Activity and Survival of Aedes Aegypti (Diptera, Culicidae). Revista Brasileira de Entomologia. 2010; 54: 488-93.

18. Nirwana T. Pengaruh Curah Hujan, Temperatur dan Kelembaban terhadap Kejadian Penyakit DBD, ISPA Dan Diare: Suatu Kajian Literatur. Repository Universitas Padjajaran. 2013.

19. Febriyani R. Pengaruh Perubahan Parameter Cuaca pada Peningkatan Angka Kesakitan 'Dengue Haemorrhagic Fever' di Kabupaten Jember. Repository Universitas Airlangga. 2010.

20. Fitriany R. Faktor Iklim dan Angka Insiden Demam Berdarah Dengue di Kabupaten Serang. Makara Kesehatan. 2010; 14.

21. Maslukha S. Hubungan Oerubahan Parameter Iklim Akibat Global Warming dengan Kasus Demam Berdarah Dengue di Kabupaten Sidoarjo. Repository Universitas Airlangga. 2010.

22. Roose A. Hubungan Sosiodemografi dan Lingkungan demgan Kejadian Penyakit Demam Berdarah Dengue (DBD) di Kecamatan Bukit Raya Kota Pekanbaru Tahun 2008. Repository Universitas Sumatera Utara. 2008.

23. Wu PC, Lay JG, Guo HR, Lin CY, Lung SC and Su HJ. Higher Temperature and Urbanization Affect the Spatial Patterns of Dengue Fever Transmission in Subtropical Taiwan. The Science of the Total Environment. 2009; 407: 2224-33.

24. Reiter P, Lathrop S, Bunning M, et al. Texas Lifestyle Limits Transmission of Dengue Virus. Emerging Infectious Diseases. 2003; 9: $86-9$. 